\section{FAMILY- DRYNARIACEAE FROM KATHMANDU, NEPAL}

\section{P.C. MISRA ${ }^{\mathrm{a} 1}$ AND SHRADDHA TIWARI ${ }^{\mathrm{b}}$}

\author{
aDepartment of Botany, Hemwati Nandan Bahuguna Govt. P. G. College, Naini, Prayagraj, U.P. India
}

${ }^{b}$ Department of Botany, Bhawan's Mehta P. G. College, Bharwari, Kaushambi, U.P. India

\begin{abstract}
The occurrence of Drynaria mollis (Bedd.) belonging to the family Drynariaceae is reported from phoolchauki, Kathmandu, Nepal. It is a epiphytic plant, rhizome long, strong and woody type, clothed with linear, golden brown with transparent ciliated scales. This species is collected in the month of December (winter season in Nepal). This plant specimens has been studied thoroughly with epidermal details. The usual technique employed by Pant school, has been employed. Epidermal peels were taken out by treating the material with Shulze's techniques of maceration. Venation pattern has been studied by making preparations of transparency using Foster's technique (Foster, 1966).
\end{abstract}

KEYWORDS: Stipe, Pinnae, Hypostomatic, Veins, Stomata

This pteridophytic species belong to family Drynariaceae Ching. This family includes terristrial or epiphytic plants with basally attached scales. Rhizomes long-creeping, strong and woody with linear, hairy scales. Fronds are of dimorphic type, sterile fronds are quite different in shape and size and these are of short or broad type with sessile and brown in colour. Fronds are pinnatified, venation reticulate type, commonly forming a complex networking of with free branched veinlets included in the areoles. Sporangia are aggregated in circular or elongated manner and superficial sori, spread all over the lower surface of the fertile fronds. The spores vary from smooth to subverrucate or spinulose exine.

\section{MATERIALS AND METHODS}

The material of this species was collected from different localities of Nepal including Kathmandu and Pokhara district. Road side collections were made to Kathmandu and Phulchoki. In Pokhara collection were mainly made near Pheva Lake and all along way from Pheva lake to World peace Pagoda, way to Gupteswar Mahadevm, Devis fall areas etc. The collected specimens were dried and treated with mercuric chloride and they are deposited in the Duthie Herbarium of Botany Department, University of Allahabad. The specimens were duly numbered. For the identification help has been taken from BSI (Central circle Allahabad) and thanks are due to Late Dr. R. D. Dixit for identified these plants.

For the study of cuticle, stomata and epidermal details, small pieces of mature pinnules were fixed in FAA. The usual technique employed by Pant school, has been employed. Epidermal peels were taken out by treating the material with Shulze's techniques of maceration. Venation pattern has been studied by making preparations of transparency using Foster's technique (Foster, 1966). Lastly it is mounted in euparol.

Spores were studied by Nair and Devi (1963) procedure. Several microchemical tests of Lignin, Cutin were made by Johnson (1940) and Foster (1966) techniques.

\section{RESULTS AND DISCUSSION}

Drynaria mollis (Bedd.)- (Text fig-14 A-F, Plates-9B, 37A-F, 38A-F). PCM CollectionNo.-12061-12065.

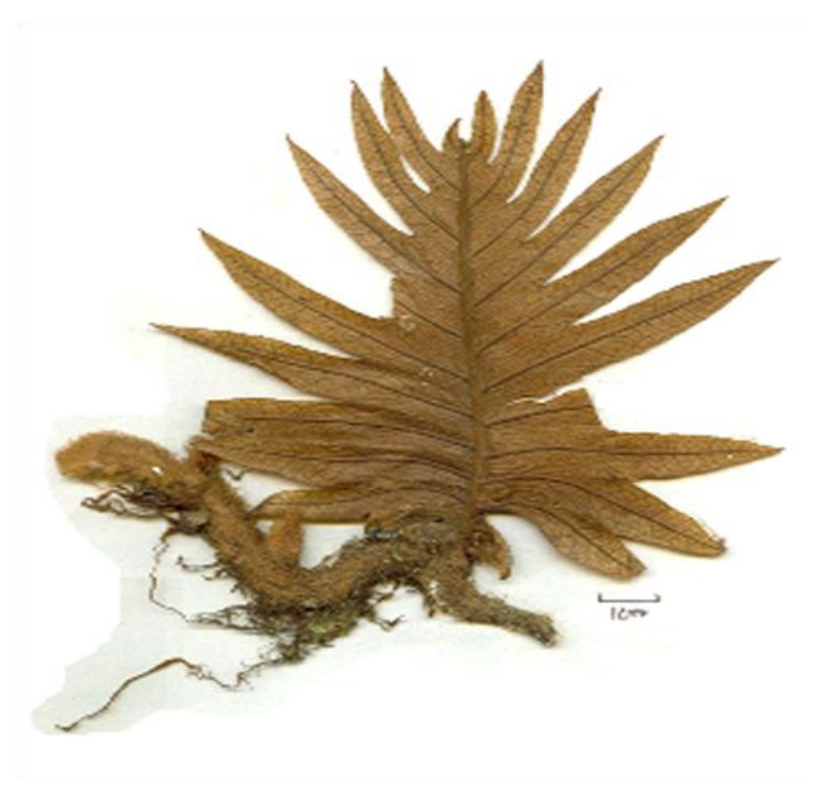

Figure 1: Plant photograph of Drynaria mollis. 


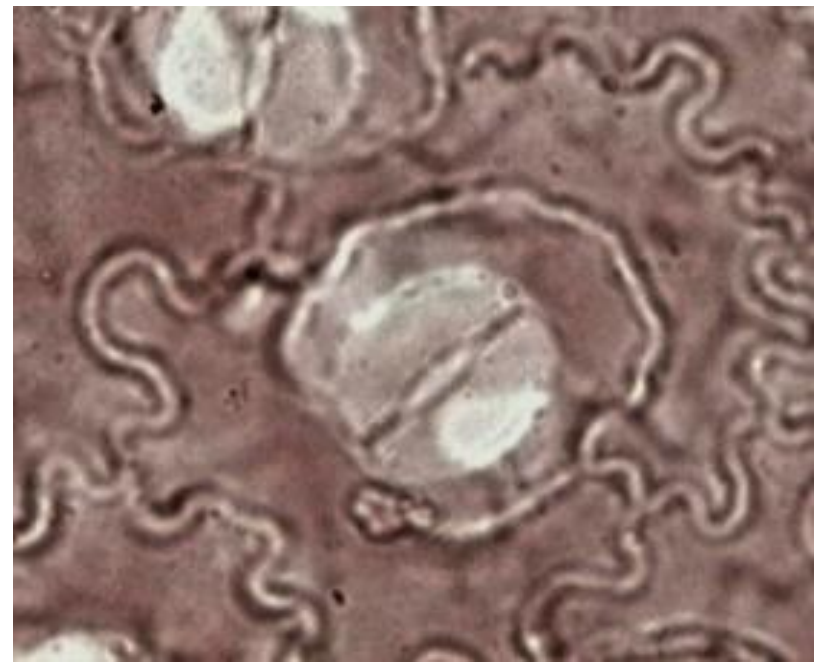

Figure 2: Lower epidermal cells with stomata X 40.

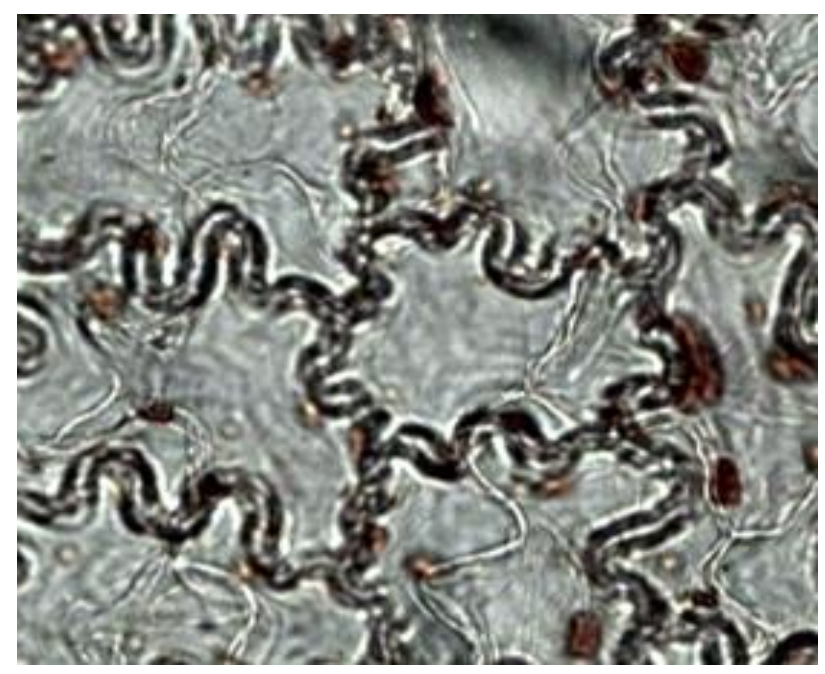

Figure 3: Upper epidermal cells without stomata X 40.

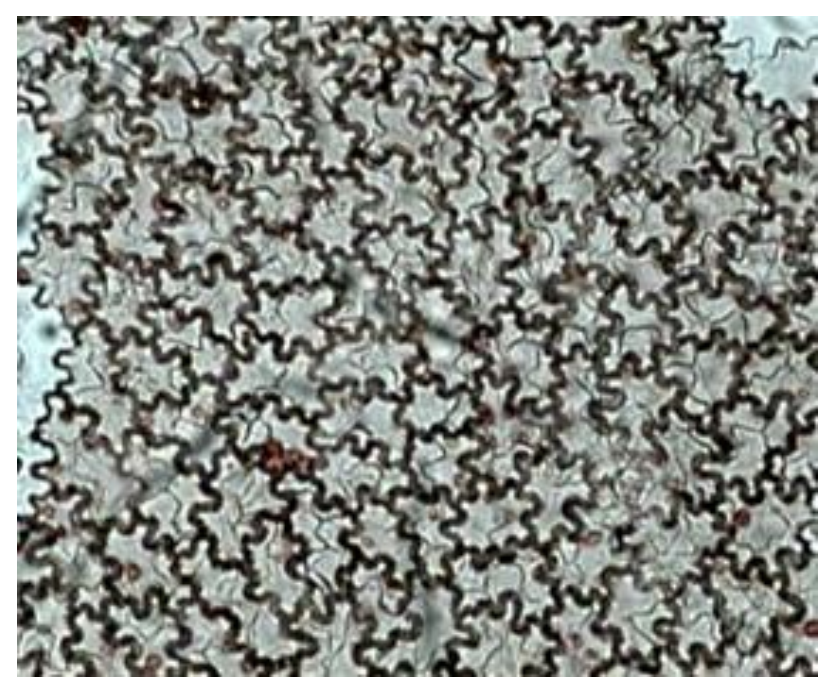

Figure 4: Upper epidermal cells without stomata X 10.

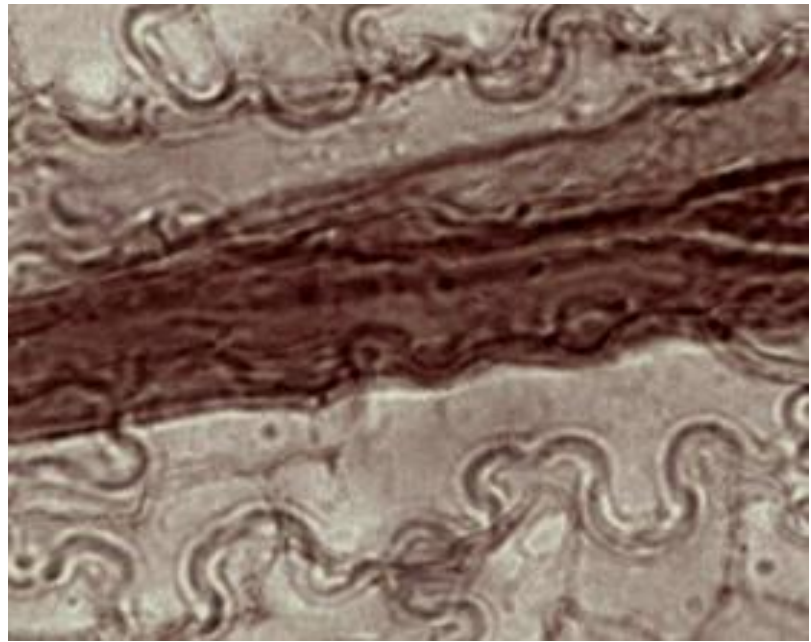

Figure 5: Upper epidermal cells of vein areas X 10.

Plant epiphytic, rhizome long, strong and woody type, clothed with linear, golden brown and transparent ciliated scales. Scales are nearly pointed at the tip and broad at the base. The entire margin of scales is filled with hair like cilia, which gives a peculiar appearance to the scales. The rhizomes are completely covered with the scales. Fronds are membranous and are dimorphic i.e. shows sterile and fertile leaves. There shape and size also vary. Pinnules are not very deeply cut till the mid rib region. Fronds are sessile and veins are present through the surface. Veins gradually forming three or four times areoles, in each areoles, veinlets are also present. The number of veinlets decreases from base to the tip of the leaf.

The venation pattern is reticulate and anastomosing type and forming a network like structure. Leaves are hypostomatic and stomata are confined to the lower sides only. Both the surfaces of epidermal cells are sinuous walled. The amplitude and wavelength of sinuosity of upper epidermal cells are $24 \mu \mathrm{m}$ and $88 \mu \mathrm{m}$ respectively while the amplitude and wavelength of sinuosity of lower epidermal cells are $43 \mu \mathrm{m}$ and $80 \mu \mathrm{m}$ respectively. Stomata are eupolo-mesoperigenous type i.e. stoma with one mesogenous cell at the pole of the guard cell. Other types of stomata are also casually seen in this genus.

Out of the three species of the Drynaria viz; Drynaria propinqua (wall.ex Mett.) J.smith, D.mollis (Bedd.), D.quercifolia (Linn.) J.smith., has been reported from different locality of Nepal (see Sinha and Gurung 1985, Gurung 1997). However the author has collected and studied only D.mollis (Bedd). Although seven species of Drynaria have been reported from other countries (see Beddome 1892). Drynaria is unique in many respect, first 
in showing dimorphism in the leaf structure. Its venation pattern is anastomosing reticulate type and areols contains peculiar veinlets. The stomata are also peculiar type i.e. eupolo-mesoperigenous type.

\section{ACKNOWLEDGEMENT}

The authors express their sincere thanks to the Head of department of botany, university of Allahabad for providing the laboratory facilities. I am very grateful to Prof. D.R. Mishra who supervised me for this study. I also pay my gratitude to Prof. D.K. Chauhan who has given me valuable suggestions. I am also thankful to late Dr. R.D. Dixit for giving me support in identification of species.

\section{REFERENCES}

Beddome R.H. 1892. Handbook to the Ferns British India, Ceylon and Malay Peninsula with supplement. Thacker Spink \& Co. Calcutta.
Foster A.S., 1966. Morphology of anstoses in the dichotomous venation of Circaeaster. Am. J.Bot., 53: 588-99 .

Gurung V.L., 1997. Primitive and Advance Characters in Some Ferns from Nepal. Bionature, 17(1): 1323.

Johansen D.A., 1940. Plant microtechnique. McGraw Hill Co. New York.

Nayar B.K. and Devi S., 1963. Spore morphology of the Pteridaceae IV Taxonomic and phyletic considerations. Grana Polynol., 8: 517-535.

Sinha B.M.B. and Gurung V.L., 1985. Phytogeographical Distribution of Pteridophyte Flora of Nepal Himalaya in Relation to Central Nepal. Indian Fern Jour., 2: 17-21. 